\title{
Correction to: Comparison of the acute toxicity, analgesic and anti-inflammatory activities and chemical composition changes in Rhizoma anemones Raddeanae caused by vinegar processing
}

\author{
Sha-Sha Wang, Shao-Yan Zhou, Xiao-Yan Xie, Ling Zhao, Yao Fu, Guang-Zhi Cai and Ji-Yu Gong*
}

Correction to: BMC Complement Med Ther 20, 7 (2020)

https://doi.org/10.1186/s12906-019-2785-0

Following publication of the original article [1], the authors identified an error and corresponding author should be Ji-Yu Gong and not Sha-Sha Wang as previously published.

Sha-Sha Wang, Shao-Yan Zhou, Xiao-Yan Xie, Ling Zhao, Yao Fu, Guang-Zhi Cai and Ji-Yu Gong*

Published online: 14 October 2020

\section{Reference}

1. Wang, et al. Comparison of the acute toxicity, analgesic and anti-

inflammatory activities and chemical composition changes in Rhizoma

anemones Raddeanae caused by vinegar processing. Complement Med

Ther. 2020;20:7. https://doi.org/10.1186/s12906-019-2785-0.

The original article can be found online at https://doi.org/10.1186/s12906019-2785-0.

* Correspondence: gjy0431@126.com

Changchun University of Chinese Medicine, Boshuo Road No. 1035, Jingyue

High-tech Industrial Development Zone, Changchun 130117, China

(c) The Author(s). 2020 Open Access This article is licensed under a Creative Commons Attribution 4.0 International License, which permits use, sharing, adaptation, distribution and reproduction in any medium or format, as long as you give appropriate credit to the original author(s) and the source, provide a link to the Creative Commons licence, and indicate if changes were made. The images or other third party material in this article are included in the article's Creative Commons licence, unless indicated otherwise in a credit line to the material. If material is not included in the article's Creative Commons licence and your intended use is not permitted by statutory regulation or exceeds the permitted use, you will need to obtain permission directly from the copyright holder. To view a copy of this licence, visit http://creativecommons.org/licenses/by/4.0/. The Creative Commons Public Domain Dedication waiver (http://creativecommons.org/publicdomain/zero/1.0/) applies to the data made available in this article, unless otherwise stated in a credit line to the data. 